\title{
DIGNITY
}

Dignity: A Journal of Analysis of Exploitation and Violence

\section{Improving Health Outcomes in Trafficking Survivors through Core Skills Development in the Workplace: Experience from the Philippines}

Melinda A. Gill

Renewsiya Foundation, melinda.gill@gmail.com

Follow this and additional works at: https://digitalcommons.uri.edu/dignity

Part of the Community Health and Preventive Medicine Commons, International Public Health Commons, Maternal and Child Health Commons, Public Health Education and Promotion Commons, and the Women's Health Commons

\section{Recommended Citation}

Gill, Melinda A. (2017) "Improving Health Outcomes in Trafficking Survivors through Core Skills Development in the Workplace: Experience from the Philippines," Dignity: A Journal of Analysis of Exploitation and Violence: Vol. 2: Iss. 2, Article 2. https://doi.org/10.23860/dignity.2017.02.02.02

This Frontline Report is brought to you for free and open access by DigitalCommons@URI. It has been accepted for inclusion in Dignity: A Journal of Analysis of Exploitation and Violence by an authorized editor of DigitalCommons@URI.For more information, please contact digitalcommons-group@uri.edu. 


\title{
Improving Health Outcomes in Trafficking Survivors through Core Skills Development in the Workplace: Experience from the Philippines
}

\author{
Abstract \\ Whilst an emerging body of research documents the adverse physical and mental health outcomes of \\ victims of trafficking following rescue, there is little research or guidance regarding interventions which \\ improve these outcomes. In this article, I describe my experience as physician involved in a computer- \\ based social enterprise for survivors of trafficking and slavery in the Philippines, and outline my evolving \\ understanding of the requirements for health behavior change and improved outcomes. I conclude that \\ while meaningful vocational skills, economic security, and adequate health-related knowledge are \\ foundational, it is necessary to develop core skills to achieve improved health outcomes and that a \\ supportive workplace is an ideal setting for this to occur.
}

\section{Keywords}

Philippines, trafficking survivors, health outcomes, behavior change, employment, core skills development

\section{Creative Commons License}

c) (i) $\ominus$

This work is licensed under a Creative Commons Attribution-Noncommercial-No Derivative Works 4.0 License.

\section{Acknowledgements}

I would like to thank my husband for his courage and perseverance in building the social enterprise and our employees for allowing us to be a part of their journey. Dignity thanks the following people for their time and expertise in reviewing this Frontline Report: Janice Shaw Crouse, Ph.D., Board Chair, Institute on Religion and Democracy, USA; Tamme de Leur, Executive Producer and Director, MetaStory Productions and Lecturer, University Applied Sciences, Ede, the Netherlands; and Anjilee Dodge, MSW, Workforce Development Coordinator, Seattle, USA. 


\section{Title: Improving health outcomes in trafficking survivors through core skills development in the workplace: experience from the Philippines}

I am a doctor. Having started my career as a Family Physician in Australia, I moved to the Philippines and into the non-governmental sector seven years ago. Two years ago, I joined my husband's social enterprise which provides computer-based work to survivors of trafficking and slavery.

My husband is not a doctor. He's not any kind of health professional. In fact, he isn't particularly interested in health issues at all. And yet, I suspect that he has had a greater impact on health outcomes since starting the enterprise than I have had as a physician and in nongovernmental work.

Three years ago, after hearing about the plight of victims of human trafficking and slavery, my husband left his job in banking to start a social enterprise providing computer-based training and employment to survivors. In the Philippines, it is estimated that more than 400,000 men, women, and children are forced into bonded labor, the commercial sex industry, or other forms of forced servitude or exploitation (Global Slavery Index 2016). Whilst awareness of the issue and preventive and rescue efforts are increasing, long-term aftercare options and rehabilitation for survivors are lacking. This is particularly true for employment options. The few that exist tend to focus on vocational training without a pathway to an actual job, or on traditional, lower-skilled work such as handicrafts or service-industry work, all of which are unlikely to provide financial independence (Richardson et al. 2009, UNIAP 2009, Armstrong 2008 p84).

The vision of the social enterprise is to provide not only a genuine career path through enhanced technical skills, but to create a context where survivors can progress towards achieving full and sustained reintegration. To date, 44 individuals have commenced training (referred to as 'recruits' in this article), including 21 victims of sex trafficking, nine victims of labor trafficking, four victims of sexual abuse, and ten individuals considered 'vulnerable.' Interestingly the lack of computer skills among the recruits has not proven to be the biggest challenge for successful employment. The lack of core skills has been a far bigger hindrance.

Core skills, also known as life skills, employability skills, or key competencies, can be defined as a "comprehensive set of universal cognitive and non-cognitive skills and abilities, connecting behavior, attitudes, and knowledge" (IYF 2015 p3). They are capabilities which are needed for success in employment and are transferable and enable success in all aspects of life (ILO 2015 p2). They are required at school, work, and home; in caring for children, for study and career, and for managing finances and health needs (Brewer 2013 p2, Center on the Developing Child 2016 p4, Babcock and Ruiz De Luzuriaga 2016 p 11, UNICEF 2012, Heckman and Rubinstein 2001). A large number of attributes are contained in core skills frameworks, including communication and teamwork, literacy and numeracy skills, and learning and thinking skills, such as focus, awareness, critical thinking, decision making, planning, and organizing (ILO 2015, Brewer 2013 p10, DEET 2013). Character traits such as responsibility, integrity, respect, self-control, and adaptability are also included. 
The recruits often lacked these skills and traits. Early childhood is the key period for core skills development, when responsive, nurturing, and stable caregivers support the healthy development of the brain, impacting brain architecture, biochemistry, and gene expression (Center on the Developing Child 2016, Knudsen et al. 2006). In many survivors of trafficking, the childhood environment has compromised this process. Whilst the determinants of trafficking are complex, survivors often come from impoverished backgrounds where, as well as the effects of poverty, they have experienced physical or sexual abuse, significant family dysfunction, and lack of a support system (Zimmerman and Pollock 2013, Joshi et al. 2012, Jobe 2010 p28, Hossain et al. 2010, Zimmerman et al. 2008, Zimmerman et al. 2006).

In addition to the dysfunction, neglect, and trauma often suffered during childhood, is the trauma experienced through trafficking, resulting in high rates of mental health issues among survivors (Kiss et al. 2015, Zimmerman et al. 2008). However, even without overt mental illness, trauma further compromises executive function and core skills (Babcock 2014 p10). Although high-quality primary and secondary education can positively impact core skills development (Brewer 2013 p 14), weak public schooling in the Philippines does not support this process. Furthermore, lack of employment opportunities for survivors in the formal economy means that core skills are not acquired in a work environment.

Some of the most significant manifestations of the lack of core skills in the enterprise's recruits were health-related. Many struggled to adequately manage their health needs. Consequently, illness-related absenteeism was high and spiked during stressful projects. We suspected binge drinking was common, and there were regular requests for cash advances for health-related expenses.

One of the greatest concerns was the frequency of unplanned pregnancies among recruits. Paula was one such recruit. She became pregnant a few months after she started training and, not knowing what else to do, ingested an illegal abortifacient which resulted in the need for emergency treatment. Sadly, at the hospital, she was retraumatized by reproachful, verbally abusive staff who refused her treatment. Although she continued with the pregnancy with the support of a psychotherapist, she could not cope with resuming employment at the enterprise and returned to prostitution.

With constant health issues among recruits, I left my job with a non-governmental organization (NGO) a year after the social enterprise was formed to focus on improving health behavior and outcomes. I provided guidance to staff as health issues arose. I developed and taught a comprehensive health and wellbeing curriculum using adult educational tools based on a well-considered behavior change theory. And over the next 12 months, we saw significant improvement in several health-related outcomes. Absenteeism declined and stayed low even during stressful projects, borrowing dropped, and overall the recruits appeared to be taking more responsibility for their health. However, even whilst observing these improvements, I knew they had little to do with me or my curriculum. As I listened to the survivors' narratives about themselves pre-and post-employment and viewed the holistic changes in their lives, I recognized that these positive changes were more a consequence of the management team's heightened efforts and evolving strategies to build core professional skills and character traits. This is likely to be a strong factor in the reduction in illness-related absenteeism. Research has documented 
high levels of physical symptoms among survivors following rescue, including fatigue, memory problems, headaches, and dizziness (Kiss et al. 2015, Crawford and Kaufman 2008, Zimmerman et al. 2006). Given the non-specific nature of these symptoms, the probability that many are psychosomatic and further triggered in stressful situations is high. Hence as our recruits developed stronger coping mechanisms, such as the ability to manage stress and anxiety, a fall in absenteeism and other transformations occurred.

In Kristalyn's journey, this transformation process was highly visible. After graduating from high school, Kristalyn had no other option but to start work as a live-in domestic worker. Upon entering the house, she was raped by her foreign employer and became his sex slave until she was eventually rescued, already pregnant with his child. Two years later she was recruited into our enterprise. As a new employee, she almost crouched at her desk in her oversized T-shirt and baggy jeans, her hair, in a short boyish cut except for the fringe, was just long enough to cover her frightened eyes. Whilst this exterior enabled her to feel safe and cope immediately following rescue, her increasing abilities and confidence allowed her to metamorphose into a more emboldened and complete version of herself. Her hair grew long, and she pulled it back off her face to reveal bright eyes and a vivacious smile. The oversized clothing disappeared and was replaced by smart business attire. Kristalyn now stands erect and strong and speaks with deep conviction, even through her tears, as she shares her story with others. She speaks of selfforgiveness and the lifting of the shame and stigma of her past; the process of becoming a professional; the importance of positive female role models among the senior management staff; and the hope that she can create a better future for herself and her young daughter. As she undertook this identity reformation and re-visioning, she acquired the motivation and selfefficacy to manage her health needs. Simultaneously, she developed core skills including problem-solving, planning, and self-control that successfully managing one's health requires. Kristalyn's increasing desire for a professional career and college degree became strong motivators for her to plan her family. This required her to critically consider the available options before choosing the contraceptive pill. She has then exercised continued planning and problemsolving skills to manage her finances and time to purchase new pills as needed, remember to take them each day, and deal with 'unsafe days' if she misses pills. The latter demands the confidence and communication skills to delay sex with her partner until she is again protected against pregnancy.

The process of personal development and core skills acquisition happens at its own unhurried pace. Unfortunately, this means that recruits are at risk of health crisis early in their employment, including unplanned pregnancies. Health and development professionals will testify that this is often not an easy outcome to change. The aftercare community similarly lament that unplanned pregnancies are common among survivors and can derail the recovery process. Addressing this issue is particularly imperative in the Philippines, where historical and cultural influences mean that there is a large unmet need for family planning and high fertility rates compared with other countries in the region (PSA and ICF International 2014 p 84, WHOWPR 2017). Among young people, $78 \%$ do not use any protection against pregnancy, and teenage pregnancies are increasing (PSA 2014, DRDF 2013 p 12). It is likely that our recruits are immersed in households and communities where most pregnancies are not planned. 
My health curriculum, which includes a strong focus on sexual and reproductive health, is implemented early in the enterprise's training program. I know the training doesn't result in any immediate change because I evaluate the curriculum using a pre-and post-questionnaire. To modify reproductive health behavior, recruits must dissociate from the typical values and behavior of their peers, in whom unprotected sex and low use of modern contraceptives is the norm (DRDF 2013, PSA and ICF International 2014 p 73). In order to adopt different behaviors, they must begin to see themselves as a working professional and envisage the possibilities that this affords. They must recognize that effectively managing their health is integral to achieving these aspirations. Hence my role is to gently support and encourage positive choices in the hope that they will avoid a major crisis whilst they undertake this transformation. When they are ready, they will put the health knowledge to use, supported by their evolving core skills.

As I ponder this, I wonder why I thought so little about the complexities of health behavior change as a physician or NGO health director. I was, of course, conscious of a patient's "readiness for change" as per the oft-taught transtheoretical (stages of change) model and attempted to use and teach my staff effective communication strategies. I have dispensed reams of health educational materials. I have developed and implemented community-based health education programs. And yet it has been the exception rather than the norm if patients or program participants made meaningful and sustained changes. Whilst there is a myriad of behavior change theories one could draw upon to explain the progress we observe in our social enterprise, I find it difficult to isolate any in particular; whether it be Bandura's social learning theory, progressive self-mastery experiences, or the cognitive-behavioral therapy approach we use in some of our training. Whilst I know some of the basic requirements for change - such as a supportive environment, economic security, and core skills development - I doubt the triggers or influences are the same for every survivor. Seemingly, each individual forges their own unique pathway, making it unlikely that the journey of recovery and reintegration will ever be easily theorized, categorized, or mapped.

These speculations fade quickly in favor of the present reality. In front of me sits Maricel, who is one of the new recruits at the start of her journey with us. She is suffering morning sickness and, although she is happily pregnant, it is unplanned. She admits it is not ideal given her partner was abusive. At least she recognized his behavior as abuse and left him - perhaps something she learnt from my health curriculum. As a survivor of child sex trafficking, I know she hasn't yet been able to firmly envisage a greatly different future for herself. She doesn't appreciate how bearing a child on her own, having just started on a new career path, and without a supportive extended family, undermines her future wellbeing. Even so, I am forced to hope, as she smiles and sincerely thanks me for my kindness and concern for her welfare. Feeling valued improves wellbeing. Gratitude improves wellbeing. A sense of wellbeing improves health-related behavior. Perhaps one day in the future, Maricel's behavior will include choosing a good man and using modern contraception. For these and other health outcomes, meaningful vocational skills, economic security, and adequate health-related knowledge are foundational. However, without the necessary core skills, these factors alone will not achieve a significant impact. To be successful in managing their health needs, or in any aspect of life, survivors must develop strong learning, thinking, planning, communication, and organization skills together with character traits such as responsibility and self-control. A supportive and responsive workplace is an ideal place for this process to occur. Thus, regardless of who is doing more, my husband and I will 
continue to integrate our approach, and together cultivate for ourselves the same core skills and traits that we nurture within the survivors; among them - perseverance and hope.

\section{REFERENCES}

Armstrong, Helen (2008), Rebuilding lives: An introduction to promising practices in the rehabilitation of freed slaves. https://www.freetheslaves.net/wp-content/uploads/2015/03/RebuildingLives2008.pdf, accessed June 2016

Babcock Elisabeth \& Ruiz De Luzuriaga Nicki (2016). Families disrupting the cycle of poverty: coaching with an intergenerational lens. Economic Mobility Pathways, http://s3.amazonaws.com/empath-website/pdf/EMPathIntergen-Families-Disrupting-Cycle-of-Poverty-Babcock-deLuzuriaga_7.15.16.pdf, access Oct 2016.

Babcock Elisabeth (2014). Using brain science to design new pathways out of poverty. Crittenton Women's Union. http://s3.amazonaws.com/empath-website/pdf/Research-UsingBrainScienceDesignPathwaysPoverty0114.pdf , accessed Sept 2016.

Brewer Laura (2013). Enhancing youth employability: What? Why? and How? Guide to core work skills. http://www.ilo.org/wcmsp5/groups/public/---ed emp/---ifp_skills/documents/publication/wcms 213452.pdf, accessed Sept 2016.

Center on the Developing Child Harvard University (2016). Building core capabilities for life; the science behind the skills adults need to succeed in parenting and in the workplace.

http://46y5eh11fhgw3ve3ytpwxt9r.wpengine.netdna-cdn.com/wp-content/uploads/2016/03/Building-CoreCapabilities-for-Life.pdf, accessed Aug 2016.

Crawford M \& Kaufman M.R (2008). Sex trafficking in Nepal: Survivor characteristics and long-term outcome. Violence Against Women, 14(8), 905-916.

Demographic Research and Development Foundation (2013), Young adult fertility and sexuality study 4, http://www.drdf.org.ph/sites/default/files/YAFS4\%20Key\%20Findings/YAFS4\%20Key\%20Findings.pdf, accessed 20th Nov 2015

Department of Education and Training [DEET], Australian Government (2013). Core skills for work developmental framework: The framework. https://docs.education.gov.au/system/files/doc/other/csfw-mappingnational.pdf, accessed Sept 2016

Global Slavery Index [GSI] (2016). Country study: Philippines, http://www.globalslaveryindex.org/country/philippines/, accessed July 2016.

Heckman James.J. \& Rubinstein Yona (2001). The importance of non-cognitive skills: Lessons from the GED training program. The American Economic Review, 91 (2), 145-49.

Hossain M, Zimmerman C, Abas M, Light M, \& Watts C (2010). The relationship of trauma to mental disorders among trafficked and sexually exploited girls and women. American Journal of Public Health, 100(12), 24429 .

International Labour Organization [ILO] (2015). Regional model competency standards: core competencies. http://www.ilo.org/wcmsp5/groups/public/---asia/---ro-bangkok/documents/publication/wcms_420961.pdf, accessed Sept 2016.

International Youth Federation [IYF] (2014). Strengthening life skills for youth: a practical guide to quality programming. http://www.iyfnet.org/sites/default/files/library/Strengthening_Life_Skills_For_Youth.pdf, 
accessed Aug 2016

Jobe Alison (2010). The causes and consequences of re-trafficking: Evidence from the IOM human trafficking database. International Organization for Migration.

https://publications.iom.int/system/files/pdf/causes_of_retrafficking.pdf, accessed Oct 2016.

Joshi S.K, Kharel J, Suwal B, Wijma B, \& Swahnberg K (2012). I have been to hell: Rescued Nepalese girls and women's experiences of trafficking to brothels in India. https://papers.ssrn.com/sol3/papers.cfm?abstract_id=1980600, accessed Sept 2016.

Kiss L, Pocock NS, Naisanguansri V, et al (2015). Health of men, women, and children in post-trafficking services in Cambodia, Thailand, and Vietnam: an observational cross-sectional study, Lancet Global Health, 3(3), e154-e161.

Knudsen E.I, Heckman J.J, Cameron J,L \& Shonkoff J.P (2006). Economic, neurobiological, and behavioral perspectives on building America's future workforce, PNAS, 103(27) 10155-10162.

Philippine Statistics Authority [PSA] (2014), Teenage pregnancy, https://psa.gov.ph/tags/teenage-pregnancy, accessed 13th Jan 2017

Philippine Statistics Authority [PSA] and ICF International (2014). Philippines National Demographic and Health Survey 2013. Manila, Philippines, and Rockville, Maryland, USA: PSA and ICF International.

Richardson D, Poudel M \& Laurie N (2009). Sexual trafficking in Nepal: constructing citizenship and livelihoods Gender. Place and Culture, 16(3), 259-278.

UNICEF (2012). Global evaluation of life skills education programmes evaluation summary. http://www.unicef.org/evaluation/files/GLSEE_Booklet_Web.pdf, accessed Oct 2016.

United Nations Inter-Agency Project on Human Trafficking [UNIAP] (2009), SIREN report: re-thinking reintegration: what do returning victims really want \& need? Evidence from Thailand and the Philippines, http://un-act.org/wp-content/uploads/2015/07/SIREN_GMS-07.pdf, accessed June 2016

WHOWPR (2017), Reproductive health: contraceptive prevalence rate, total fertility rate, unmet need for family planning, http://www.wpro.who.int/reproductive_health/data/en/, accessed Feb 2017

Zimmerman C \& Pocock N (2013). Human Trafficking and Mental Health: "My wounds are inside; they are not visible." The Brown Journal of World Affairs, XIX(II), 265-280.

Zimmerman C, Hossain M, Yun K, e al (2008) The Health of Trafficked Women: A Survey of Women Entering Posttrafficking Services in Europe, Am J Public Health, January; 98(1): 55-59

Zimmerman C, Hossain M, Yun K, Gajdadziev V, Guzun N, Tchomarova M, Ciarrocchi R, Johansson A, Kefurtova A, Scodanibbio S Motus M, Roche B, Morison L, \& Watts C (2008). The health of trafficked women: A survey of women entering post-trafficking services in Europe. American Journal of Public Health, 98(1), 5559.

Zimmerman C, Hossain M, Yun K, Roche B, Morison L, and Watts C (2006). Stolen smiles: a summary report on the physical and psychological health consequences of women and adolescents trafficked in Europe. The London School of Hygiene \& Tropical Medicine, http://www.lshtm.ac.uk/php/ghd/docs/stolensmiles.pdf, accessed Oct 2016. 
Gill: Improving Health Outcomes in Trafficking Survivors

Page 7 of 7

Published by DigitalCommons@URI, 2017 